$\mathbf{y}_{\text {Teknologinen tiedostamaton Johannes }}$ Ekholmin romaanissa Rakkaus niinku ja Sisko Savonlahden romaanissa Ehkä tänä kesänä kaikki muuttuu

Hanna Huhtinen 
istä kumpuaa pakonomainen tarve olla jatkuvasti läsnä M sosiaalisen median kanavilla (Seymour 2019)? Problematiikkaa käsitellään suomalaisessa nykyfiktiossa. Länsimaiden digitalisoitumisen seurauksena kotimaisessa proosassa esiintyy 2000-luvun ensivuosikymmeninä tuon tuostakin intermediaalisia digitaaliteknologian kuvauksia (ks. Malmio 2019, 197; Hietasaari 2011, 76-78), ja enenevästi myös sosiaalisen median alustojen käytön kuvausta. Tässä artikkelissa erittelen aihetta kahdessa romaanissa: Sisko Savonlahden Ehkä tänä kesänä kaikki muuttuu (2018, tästä eteenpäin ET) ja Johannes Ekholmin Rakkaus niinku (2016, tästä eteenpäin RN). Teosten digitaalisen kulttuurin käsittelytavat ovat rakenteen ja kielen tasoilla erilaiset, mutta sosiaalinen media ja muu teknologiavälitteinen vuorovaikutus esitetään molemmissa keskeisenä osana päähenkilöiden arkielämää, ihmissuhteita ja työllistymisnäkymiä.

Tarkasteltavien teosten viittaukset digitaaliseen kulttuuriin ja sosiaaliseen mediaan ovat moninaiset. Henkilöhahmojen käytössä ovat muiden muassa Facebook, Tinder, Google Hangouts -chat ja vauva.fi-sivusto kommenttiosastoineen. Kuvataan siis monimuotoista verkkoviestintää, johon käytetään älypuhelinta tai muuta älylaitetta. Teknologiavälitteinen viestintä perustuu monikanavaisuuteen ja -aistisuuteen, ja samalla syntyy käyttäjien yhdessä tuottamaa digitaalista sisältöä. (Suominen et al. 2013, 13-17.) Sosiaalisen median käyttö on molempien teosten teemoja: sanataiteellinen kompositio keskittyy someviestintään ja etsii aikalaiskulttuurin hahmottamisen tapoja.

Savonlahden romaani on lakoninen ja postauksittain etenevä kuvaus työttömästä naisesta, joka etsii elämäänsä merkitystä somesta. Ekholmilla päähenkilö on kolmekymppinen, työtön ja koditon Joona, joka etsii toimeentuloa tallentamalla ja julkaisemalla omaa arkeaan. Teokset imitoivat somekielen rekisterejä ja kuvaavat diginatiivien tarvetta tehdä pesäeroa yhtenäiskulttuuria edustavaan vanhempaan sukupolveen. Esittelen ensin teosten päähenkilöitä teknologiavälitteisyyden näkökulmasta. Sitten käsittelen teknologisoitunutta arkea, ja lopuksi avaan henkilöhahmojen toimintaa teknologisen tiedostamatto$m^{1}{ }^{1}$ kannalta. Teknologisella tiedostamattomalla (Thrift \& French 2002, 312; Thrift 2005, 177) tarkoitan tietoisen havaitsemisen ulkopuolelle jäävää, piiloista ohjelmistoitumisen ${ }^{2}$ logiikkaa, joka ulkoa annettuna itsestäänselvyytenä jäsentää ja rytmittää ihmisten jokapäiväistä toimintaa ja herättää vaikeasti eriteltäviä tunteita (Saariketo 2018, 38; 2020, 23).

Kirjallisuudentutkimuksessa teknologisen tiedostamattoman käsitettä muistuttaa Zara Dinnenin (2018) näkemys digitaalisesta banaalista, jossa digitaaliteknologian vaikutukset arkeen normalisoituvat arkisiksi käytännöiksi, samalla kun taustalla vaikuttavat, retoriset, sosiaaliset, poliittiset, materiaaliset ja ohjelmistoihin perustuvat seikat jäävät käyttäjiltä huomioimatta. Myös Jeremy Glazer, Robyn Seglem ja Antero Garcia (2021, 675-676, 679-680) pitävät kaunokirjallisuudessa esiintyviä realistisia ja ajanmukaisia teknologia- 
representaatioita keskeisinä aikalaiskokemuksen välittäjinä, mutta viestintäteknologian kuvauksen kannalta kyse on sekä jatkumosta että muutoksesta. Tietyt teemat pysyvät ajattomina eikä uusien teknologioiden läsnäolo tuota automaattisesti uusia kirjallisia keinoja. Muutos koskee erityisesti sosiaalisen median esityksiä: viraali-ilmiöt kaiuttavat henkilöhahmon kokemuksia - esimerkiksi suosion kaipuuta tai itseinhoa - ja mahdollistavat anonyymit alter egot, joiden kautta tapahtuva vuorovaikutus yleisöjen kanssa muuttaa päähenkilön sosiaalista maisemaa tavalla, joka ei olisi mahdollinen ilman uusia medioita.

Vaikka media- ja teknologiakehityksen taustalla vaikuttavassa digitalisaatiossa on kyse megatrendistä, aihetta on toistaiseksi tutkittu niukalti kaunokirjallisessa representaatiossa. Teknologinen kehitys ja sen myötä uudet mediat vaikuttavat siihen, miten kommunikoimme ja ajattelemme. Tällä on seurauksia myös aikalaiskirjallisuuteen. Uusimpia teknologiainnovaatioita käsittelevät teokset hahmottuvat kirjallisuudeksi, joka reagoi luovasti muuttuvaan mediamaisemaan. (Glazer et al. 2021; Weigel 2018.) Laajemmassa mielessä aiempi tutkimus on tarkastellut sitä, mitä sosiaalisia, kulttuurisia ja välittäviä tehtäviä digitalisaatiota sivuava kirjallisuus täyttää (Dinnen 2018; Glazer et al. 2021; Weigel 2018). Osallistun tähän orastavaan keskusteluun tarkastelemalla kotimaista proosaa.

Artikkelini lähtökohta on, että digitalisaatiokehityksen viitekehyksessä yksi ajankohtaisimmista kaunokirjallisista teknologiarepresentaatioiden muodoista on juuri sosiaalisen median ja pikaviestittelyn kuvaus. Niiden edustus kotimaisessa kirjallisuudessa on merkittävä ilmiö. Digitalisaatio, sosiaalinen media ja huomiotalous ${ }^{3}$ ovat nykykulttuuria ja käsittelemääni teosparia yhdistäviä kattokäsitteitä.

Kun kahden perinteisesti erilaiseksi määritellyn ilmaisuvälineen - tässä kaunokirjallisuuden ja sosiaalisen median - välillä on osoitettavissa merkityksen muodostumiseen vaikuttava yhteys, puhutaan intermediaalisesta suhteesta (Rippl 2015, 12). Esitän, että sosiaalisen median käyttö johtomotiivina ja sen mahdollistavat laitteet esinemotiiveina ovat intermediaalisia elementtejä, joita tarkastelemallaa aikalaiskuvauksen tematiikka hahmottuu. Esimerkiksi Savonlahden teoksen kohdalla on koettu, että sen päähenkilö on "vailla rytmiä ja elämänhallintaa" (kirjallisuusblogi Luettua ja maistettua 19.9.2018; ks. myös Logrén 2020, 129-131). Esitän molempien teosten arjen rytmiikan kytkeytyvän sosiaalisen median käyttöön ja teknologiseen tiedostamattomaan. Kysyn, miten romaanien henkilöhahmojen arki rytmittyy ja mikä romaaneissa synnyttää arkisien tapahtumien taltioinnin tarpeen. Argumentoin, että teknologisen tiedostamattoman käsite auttaa hahmottamaan kaunokirjallisten somejulkaisijoiden kuvauksen olennaisia piirteitä ja samalla aikalaiskuvauksessa näkyviä laajempia kulttuurisia virtauksia. 
Savonlahden teos kertoo nimeämättömän päähenkilön elämästä ennen ja jälkeen parisuhteen, joka saa alkunsa someviestittelystä. Teoksen alussa kuvataan seurustelun alkua, yhdessä asumista ja eroa. Seurusteluaika on tunnelmaltaan toiveikas verrattuna kuvaukseen ajasta eron jälkeen. Some rytmittää päähenkilön toimintaa läpi teoksen. Esimerkiksi viestittely pikaviestipalveluWhatsAppissa kuvastaa parisuhteen tilaa: "Näin helppo meidän on pitää yhteyttä toisiimme, emmekä siitä huolimatta enää tee niin" (ET, 13).

Ekholmin romaanin päähenkilö Joona ei pelkästään rakenna omaa someprofiiliaan, vaan kanssakäyminen ja ihmissuhteet valjastetaan arvonmuodostuksen välineeksi tallentamalla ja litteroimalla. Näin on tapana tehdä tietyissä kaupallis-esityksellisissä somejulkaisuissa esimerkiksi Instagramin ja Facebookin verkkokauppaominaisuuksissa sekä blogeissa, joissa merkityksiä luodaan autenttisuuden, identiteetin ja kulutuskulttuurin ristivedossa (Noppari \& Hautakangas 2012). Tallentamastaan raakamateriaalista Joona koostaa romaania. Kuvattujen dialogien ja tapahtumien autenttisuutta korostetaan transkriptioilla, jotka sisältävät sekä muistiin kirjattua puhetta että ei-äänteellistä kontekstia kuvaavia sulkuviitteitä, parenteeseja. Teos alkaa lokitiedoista koostuvalla sisällysluettelolla. Luetteloa seuraava esipuhe luo vaikutelmaa siitä, että kyseessä on autenttinen julkaisu: "Seuraavat keskustelut on käyty yhden viikon aikana keväällä 2016. Koska osa keskusteluista on taltioitu yhden tai useamman osallistujan siitä tietämättä, on puhujien nimet muutettu. Äänitteet olen omavaltaisesti litteroinut kirjalliseen muotoon”. (RN, 7.) Toteutustapa tekee romaanista näennäisdokumentin ja lähestymistavasta metafiktiivisen. Alkusanojen allekirjoitus on romaanin päähenkilön. Sukunimen paikalla on $\mathrm{X}$-kirjaimia ikään kuin kyseessä olisi todellinen, anonymisoitu henkilö nimeltä "Joona XXXXXX" (RN, 7).

Romaanin tapahtumat rakentuvat mise en abyme -rakenteen eli romaani romaanin sisällä -kirjoittamisprosessin ympärille. Koska parenteesit ovat teoksen maailmassa päähenkilön tekemiä ja dialogit niin ikään hänen tuottamaansa litteraatiota, kyseenalaistuu kerronnan hierarkia: kertoja häivytetään. Tunnistettavissa on päähenkilökertoja mutta ei varsinaista minäkertojaa, koska kerronta rakentuu suurelta osin litteroidun dialogin, chat-keskustelujen, lokitietojen ja parenteesien avulla, jolloin vaikutelma on - teoksen itsensäkin mukaan - "oikeuspöytäkirjamainen" (RN, 213). Nämä keinot korostavat metafiktiivisesti teoksen draamallisuutta, dokumentaarisuutta ja autenttisuutta. Romaanin chat-jaksot puolestaan imitoivat sosiaalista mediaa visuaalisesti ja kielellisesti.

Savonlahden teos sisältää tavanomaisempia proosan keinoja. Tyyli on lakoninen, sisältö arkisten tapahtumien raportointia ja tapahtumat etenevät sosiaalisen median käytön rytmissä. Rakenteellisesti teos koostuu luvunmittaisista jaksoista, jotka on otsikoitu tyypillisten minämuotoisten somejulkaisujen 
tapaan: "Tein jotain" (ET, 79). Kaikkien lukujen nimet ovat kuin päivityksiä tai tiivistelmiä päivitysten sisällöistä. Ne ovat hyvin subjektiivista viestintää: "Kävin ensimmäisillä treffeillä" (ET, 22), "Sain poikaystävän!" (ET, 38), "Kerroin hänelle sipseistä" (ET, 42). Sosiaalisen median ulkoasun metatietoja, kuten päivämääriä ja käyttäjänimiä ei kuitenkaan jäljitellä toisin kuin esimerkiksi sähköpostiromaaneissa. Teoksen intermediaaliset yhteydet syntyvät muun muassa viittauksista uusiin teknologioihin ja medioihin sekä postauksia muistuttavasta minäkeskeisestä banaalin raportoinnista.

Päähenkilön tapa raportoida lakonisesti kutsuu lukemaan tyylivalintaa sekä Facebook-narratologisessa (Mäkelä 2019) että temporaalis-kokemuksellisessa (Fludernik 2003) kehyksessä. Huomio kiinnittyy kielellisten valintojen ja kertomusteoreettisten konventioiden limittymiseen erityisesti tietoisuuden representaatioissa. Esimerkiksi kerrotun kokemuksen ja merkityksettömän tapahtuman väliset tulkinnalliset jännitteet korostuvat tapauksissa, joissa kielellis-kirjallinen valinta liittyy kokijaan ja aikamuotoon. Kun kertova ja kokeva minä sulautuvat minämuotoisen preesens-aikamuotovalinnan välityksellä yhteen, voi esitys olla samanaikaisesti kohosteinen ja monotoninen implikoiden päähenkilön kyvyttömyyttä nähdä kokemustaan merkityksellisenä (Mäkelä 2019, 171). Preesens etualaistaa kerrottua kokemusta, jonka raportointi voi korostaa arkisia mitättömyyksiä. Minämuotoinen preesens mahdollistaa kerronnan ilman ulkopuolista, jälkikäteistä reflektointia, mistä seuraa vaikutelma kokemuksen ja raportoinnin samanaikaisuudesta. (Fludernik 2003, 123, 126.) Osa postaustyyliä jäljittelevistä otsikoista onkin kirjoitettu preesensissä (kävelen), jotta julkaisujen reaaliaikaista luonnetta on mahdollista imitoida. Esimerkiksi "Kävelen Kalliossa" -päivitys (ET, 301) saa kirjaimellista merkitystään kohosteisemman tulkinnan implikoimalla, että tavanomaisessa tapahtumassa on jotakin jakamisen arvoista, uutiskynnyksen ylittävää. Savonlahden päähenkilö raportoi tunne- ja kokemusmaailmaansa sekä ympäristönsä ja aikansa ilmiöitä. Raportointityylin (Savonlahti) ja chat-dialogin (Ekholm) käyttö viittaa siihen, että molemmat teokset pohtivat, näinkö nykyihminen kommunikoi. Pidän teosten intermediaalisia motiiveja, arkista raportointia ja postausrakennetta sekä somekielen ja -typografian jäljittelyä reaktiona piiloiseen ohjelmiston logiikkaan perustuvaan somekulttuuriin ja laajemmin digitaaliseen kulttuuriin.

Molempien romaanien päähenkilöt ovat itseriittoisia, ja Savonlahden päähenkilö on minäkertojaksikin erittäin subjektiivinen. Hän ei pysty olemaan empaattinen tai näkemään toisen silmin. Hän on kääriytynyt itseensä ja omiin tarpeisiinsa eikä ratko omia ongelmiaan vaan hakee huomiota somesta ja terapeutilta. Itseen keskittyminen saa samoja lannistuneita piirteitä kuin Joonan käytös romaanissa Rakkaus niinku. Joona on kommunikoivinaan mutta ohittaa toisten viestit, sillä oma identiteettiprojekti jättää muut merkitykset huomiotta. Useat sivuhenkilön asemassa olevat ystävät pyytävät häntä lopettamaan taltiointiprojektin ja keskittymään yhteiseen hetkeen, mitä Joona ei kuitenkaan tee. Myös itseriittoisuutta 
pidetään somejulkaisijoiden käyttämien somealustojen ohjelmistojen logiikan sivutuotteena, sillä julkaisualusta kutsuu itsekorostamiseen (Ridell 2011).

Teoksia yhdistää myös näkymä siitä, että julkaisija kilpailee huomiotalouden markkinoilla ja etsii ratkaisuja ongelmiinsa sosiaalisen median kautta. Kummallakaan pähenhkilöllä ei ole työsuhdetta eikä persoonallisuudelle löydy muualtakaan kokonaisvaltaista toteutumisen tilaa. Heillä ei ole merkittävää osaa muiden elämässä. Myös sukulaisuussuhteissaan he ovat jonkinasteisessa kiitollisuudenvelassa eivätkä ole saavuttaneet samoja ulkoisia statuksia kuin vanhempansa (puoliso, perhe, ura, asunto). Teknologiavälitteisen identiteetin työstäminen chatissa tai somealustoilla vaatii panostusta muttei pelasta merkityksettömyyden kokemuksilta.

Huomiotaloudessa data on arvoa: "Me kaikki tuotetaan arvoa koko ajan" (RN, 11). Joonan chat-keskustelukumppani, SAD91RL-niminen henkilöhahmo, kritisoi: "[M]ust on aina surullista et oman hyvinvoinnin ja ystävyyden valjastaa osaks työtä ja arvonmuodostusta" (RN, 181). Joona väittää vastustavansa spektaakkeliyhteiskuntaa mutta toteuttaa silti pakonomaista tarvetta yhdistyä datavirtaan ratkaisuna talous-, status- tai identiteettiongelmiinsa. Ekholmia haastatellut Jaana Seppänen $(2016,42)$ arvioi Joonan elävän niin materialistisessa maailmassa, että kielestä ja sanoista tulee "hintalappuja, jotka ilmaisevat sosiaalista statusta". Tällaisessa miljöössä yksilön arvo määräytyy sen mukaan, miten kyvykkäästi hän osaa statustaan ja arvoaan kehittää. Materiaaliset arvot eivät kuitenkaan riitä tuomaan henkilöhahmoille merkityksellisyyden tunnetta vaan hyväksynnän kaipuu puskee läpi moniin chat-keskusteluihin ja kasvokkaisiin sosiaalisiin tilanteisiin.

Savonlahden päähenkilö kuvaa työllisyys- ja talousnäkymiään: "[O]len ammatillisessa umpikujassa. En tiedä, mistä kaltaiseni toimittaja voisi enää kirjoittaa". (ET, 15.) Toimittajan työn murros liittyy olennaisesti 2000-luvun alun digitalisaatioon ja ajankuvaan (Pietilä 2018; Sarja 2016) ja yhdistää Ekholmin ja Savonlahden päähenkilöitä: kumpikaan ei enää pysty elättämään itseään toimittajana. Sisällön tuotannon kasvu on ollut huomattavaa, koska somessa kuka vain voi julkaista mitä vain lähes reaaliajassa. Toimittajan työn haastavista tulevaisuusnäkymistä seuraa taloudellista riippuvuutta vanhemmista, ystävistä tai elinkumppanista. Ekholmin romaanissa yhdessä asuminen vertautuu ennemmin perustuloon kuin perhe- tai rakkaussuhteisiin (RN, 345). Molemmat päähenkilöt pyrkivät torjumaan työttömyys- ja riippuvuusahdinkoa teknologian tarjoamilla keinoilla. Joona haluaa elättää itsensä "autenttisilla" tallenteilla, jotka julkaistaan netissä ja lopulta kirjana. Savonlahden päḧhenkilö käyttää selviytymiskeinonaan henkistä irtautumista, eli hän lamaantuu, masentuu ja etsii mielihyvää somen kautta erilaisista sovelluksista.

Henkilöhahmojen ajoittaisesta teknologiatietoisuudesta huolimatta ohjelmiston logiikka etualaistuu. Joona osoittaa toisinaan mediakriittistä asennetta mutta sortuu silti dataistiseen ${ }^{4}$ narsismiin. Hän puhuu somerepresentaatioiden harhaanjohtavuudesta kuin oppikirja mutta olettaa chat-kaverinsa SAD91RL:n 
olevan "mielikuviaan vastaava lihallistuma" (Seppänen 2016, 43). Tämä kuitenkin huomauttaa Joonalle, että internetissä kuka vain voi olla mitä vain, eikä SAD91RLhenkilöhahmon nimeä tai sukupuolta määritellä missään vaiheessa. Nimimerkki voi viitata esimerkiksi syntymävuoteen (91) ja sukupuoleen (girl). Koska se kirjoitetaan asussa SAD91RL, assosioituu se myös nettislangilyhenteeseen IRL (In Real Life) ja siihen, että joku on autenttisessa todellisuudessaan surullinen (sad in real life). Onnettomaan tunnetilaan viittaamista voi pitää vastadiskurssin muotona itsekehua ja hyvän elämän narratiivia normina suosivassa someympäristössä (Purokuru \& Paakkari 2015, 163). Joona ohittaa tämän vihjeen.

Somejulkaisija suuntaa teknologiavälitteisen viestinsä yleisölle ja odottaa vastavuoroisuutta. Kyseessä on nykyaikaisen identiteettityön keskeinen tekniikka (ks. Östman 2015), joka on tullut kaunokirjallisuuden käsittelyyn sosiaalisen median yleistymisen myötä. Älylaitteiden ympärille on kehittynyt keskeisiä päivittäisiä rutiineja, joita ohjelmistot järjestävät (Saariketo 2018, 37). Megatrendille tyypillisesti digitalisaatio on kolonisoinut länsimaisen ihmisen tilan ja ajankäytön niin perustavasti, ettei järjestäytynyttä yhteiskuntaa tai omia toimintatapoja osata enää kuvitella ilman ohjelmistoja, sovelluksia ja älylaitteita (Kitchin \& Dodge 2011). Sosiaalisen median sekä teknologiavälitteisen kommunikaation representaatioilla luodaan analysoitavissa teoksissa ajankuvaa, jossa molemmat päähenkilöt kokevat elämänsä valuvan hukkaan. Arki näyttäytyy epävapaana ja vieraannuttavana.

Erkki Seväsen (2011, 40-42) mukaan vieraantumisen käsitteellä viitataan pätkätyöhön ja syrjäytymiseen tilanteessa, jossa ihminen ei voi kehittää omia kykyjään ja toteuttaa itsessään olevia potentiaaleja: hän ei kykene tulemaan sellaiseksi ihmiseksi, joka hän voisi olla. Tämän seurauksena yksilö ei kykene kiinnittymään yhteisöihin muun muassa siksi, että hänen omassa elämismaailmassaan ei ole aitoa, myönteistä yksilöllisyyttä. Koska perinteinen vieraantumisen käsite ei tunnu sosiaalisen median representaatioiden yhteydessä riittävältä, voidaan paremman termin puuttuessa puhua teknologisen tiedostamattoman vaikutuksista arkeen. Lähestyn seuraavaksi henkilöhahmojen elämäntilanteita jäsentelemällä niitä teknologisen tiedostamattoman käsitteen avulla.

\section{Teknologisoitunut arki}

Toimittaja-kirjailija Artemis Kelosaari (2020) toteaa Parnassossa, että uuden vuosituhannen yksilön "pitää olla ylpeästi heikko ja puhua tunteistaan", ja siksi kriitikoiden suosiota saavat "Sisko Savonlahden kaltaiset kirjailijat, joiden päähenkilöt loistavat banaalilla avuttomuudellaan". Savonlahden teoksen kytkeytymistä arjen rytmiin ei käy kiistäminen. Myös Ekholmin romaani sisältää runsaasti toimettoman digiarjen kuvausta ja tunnetilitystä. Kiinnostavaa arjen kuvauksesta tekee ensinnäkin se, että arki ja arkipäiväiset asiat ovat demokraattisesti kaikkien aluetta (Felski 2000, 85). Toiseksi arjen tarkastelusta tulee 


\section{Teknologinen kehitys ja sen myötä uudet mediat}

vaikuttavat siihen, miten kommunikoimme ja

ajattelemme.

tarkoituksenmukaista, kun huomaa, että ajantuntua ja toimintaa rytmittää voimakkaasti teknologian läsnäolo.

Arjen teknologisoitumisen näkökulmasta Savonlahden ja Ekhomin teokset edustavat ennemmin teknologisen tiedostamattoman käsittelyä kuin pelkkää banaalia puuhastelua. Toimetonta aikaa kuluttaessaan Savonlahden päähenkilö tulee luetelleeksi ajanhetken käytetyimmät sovellukset (YouTube, Facebook, LinkedIn, Tinder, WhatsApp, Jodel, vauva.fi, Twitter ja Instagram) ja käyttää niitä aktiivisesti kuin tekisi kaupallista yhteistyötä, vaikkei hyödy niiden käytöstä taloudellisesti. Ekholmin romaanissa markkinavoimien värittämästä digimaisemasta (ks. myös Ojajärvi et al. 2018, 40; Piippo 2019, 213-215) ja somesta etsitään viihdettä ja vetoapua taantuneisiin uranäkymiin. Vaikka suhde someen on hetkittäin ironinen, päähenkilön toiminta edustaa teknologista tiedostamatonta, ulkoa annettua toimintamallia. ${ }^{5}$

Arki on aluetta, jonka toistuvuuksia ei ehdi miettiä kriittisesti. Päivittäin tai usein toistuvat asiat liittyvät esimerkiksi oleskeluun ja kuluttamiseen. (Felski 2000, 78-80, 93.) Juuri arkiset somesovelluksiin liittyvät valinnat ohjaavat romaanien päähenkilöitä toimimaan ristiriitaisesti: he palaavat samojen rutiinien pariin, vaikka ne tuottaisivat pahoinvointia. Savonlahden ja Ekholmin päätös kuvata arkisia toistuvuuksia romaaneissaan vaikuttaakin temaattiselta. Ehkä pätkätyöläinen tekee teknologisen tiedostamattoman ohjaamana kaiken - myös arkiset toistuvuudet - toinen silmä julkaisua ja tulonlähdettä etsien. Megatrendien näkökulmasta niin kuuluukin tehdä pärjätäkseen.

Someteosten analyysin yhteydessä (ks. Hsu 2016, 206) on todettu, että dataistinen suhtautuminen - tai jopa sulautuminen - digitaalisiin laitteisiin, kuten älypuhelimiin ja kannettaviin tietokoneisiin, näyttäytyy subjektin ratkaisuyrityksenä sosiaalisiin ongelmiin. Joonan tulevaisuudennäkymät ovat pessimistiset: "Mun elämä valuu hukkaan" (RN, 247). Älylaitetta käyttäessään hän kuitenkin kokee olevansa tärkeiden merkitysten äärellä: "Must ainakin tuntuu että mun elämän ainoot oikeesti merkitykselliset kohtaamiset tapahtuu tällä hetkellä Google Hangoutsissa ja WhatsAppissa" (RN, 101). Hän viittaa myös toiminnan immersiiviseen puoleen: "[K]un mä tuijotan mun puhelinta niin on aika todennäköistä, että mulla on käynnissä joku intensiivinen tiedonhankintatai ajatustenvaihtoprosessi, joka vaatii mun kaiken keskittymisen [--]" (RN, 101). Lähes samoin tilannetta kuvataan Savonlahden romaanissa. "Mitä minä 
oikein haluan?” (ET, 14) kysyy päähenkilö ja etsii vastausta deittisovelluksesta ja verkostoitumisalgoritmeihin perustuvilta alustoilta, kuten Facebookista ja LinkedInistä. Vuorovaikutusmuotoihin kehittyy omalakista normistoa muun muassa siitä, kuinka yhteistä merkitysmaailmaa rakennetaan. Teknologiavälitteisyyden seurauksena yksilö joutuu perustelemaan erityisesti sitä, jos ei ole tavoitettavissa online. (Licoppe 2004, 153-154.)

Molemmissa teoksissa älylaite edustaa itsen jatketta. Ajatus luonnollisesta ja autenttisesta itsestä korvautuu minällä, joka ohjautuu teknologiavälitteisten mahdollisuuksien mukaan. Teoksien kuvaama teknologinen tiedostamaton johtaa inhimillisen hyvinvoinnin kannalta epäloogisiin ratkaisuihin pitkälti siksi, että liikkuva, notkean modernin subjektius (Bauman 2002) sopii markkinavoimien intresseihin (ks. myös Lummaa \& Rojola 2014, 27). Ekholmin ja Savonlahden romaaneissa teknologinen tiedostamaton vaikuttaa päähenkilöiden arjen toimintoihin ohjaamalla työtöntä subjektia arvonmuodostukseen, mihin somealusta ohjelmistoineen tarjoaa tilaisuuden. Samalla digitaalisen huomiotalouden synnyttämä riittämättömyyden tunne sisäistetään (Purokuru \& Paakkari 2015, 165).

Arvonmuodostuksen ehdoilla toimiva julkaisija perustaa motiivinsa katsojalukuihin. Kuvahyödykkeiden valikointi - valitseminen ja hylkääminen - toimii myös someprofiilien ja niiden takana vaikuttavien ihmisyksilöiden valikointiin. Esimerkiksi Instagram ja Tinder toimivat kuvatavarataloina (termistä ks. Sihvonen 2014, 91), joiden tarjonta on globaalia ja lähes rajatonta. Siksi päähenkilöt käyvät säännöllisesti tarkistamassa somesovelluksiensa uusimman sisällön. Teknologisen tiedostamattoman logiikkaa kritisoi Rakkaus niinku -romaanissa SAD91RL:

$[\mathrm{M}]$ ietin et miten arkiseks on tullu omaksuu sellane "esityksellinen" suhde virtualiyleisön katseen kohteena olemiseen ja vapaaehtosesti paljastaa ittensä esim kuvassa joka jaetaan vaik instassa ja miten tottuneit me ollaan kuvittelemaan ittemme kulutustavarana joka kerää arvoo sen mukaan miten se ilmentää jotain tiettyy positioo [--]. pelottaa et mitä se tekee tunne-elämälle ja pystyyks kohdata enää ketään "vaan ihmisenä" jos on sisäistäny ne pelin säännöt ja tiedostaa sen rankingin niinku kandeeks tän tyypin "osakkeit" ostaa vai myydä swaippaaks aina left jos joku on hyödytön (RN, 174-175.)

Joonan ja SAD91RLin virtuaali-ihmissuhde kriisiytyy Joonan harjoittaman hyödyntavoittelun seurauksena. SAD91RL muotoilee ongelman näin: "[A]inoo mitä mä toivon on että sä kohtelet mua ihmisenä etkä redusoi mua joksi sun konseptiks [--]. sä et kunnioita meidän ystävyyttä sä riistät mun kognitiivist ja affektiivist työtä”. (RN, 173.) Kyllästyttyään lopullisesti Joonan itseriittoiseen tapaan viestiä SAD91RL katkaisee chat-suhteen:"[SAD91RL WENT OFFLINE]" (RN, 280).

Myös Joonalle ja tämän ystävälle Caritakselle tulee sanaharkkaa someen liittyen. Caritas syyttää Joonaa siitä, ettei tämä "tykkää" Caritaksen Instagram- 
kuvista riittävän usein. Joona puolustautuu ja sanoo kyllä tykkäävänsä aina kun kokee tietyn kuvan kiinnostavana. Siispä somevälitteisen kommunikaation laskennallisuudesta seuraa ohjelmiston logiikan mukaista laskelmointia. Vilpitön "tykkääminen" ei Caritaksen mielestä riitä vaan pitäisi tykätä aina ja vastavuoroisesti, koska siitä on hyötyä molempien näkyvyyden kannalta. (RN, 76-77.) Caritaksen asenne viittaa tykkäysvelvollisuuteen, mikä on sisäistettyä ohjelmiston logiikkaa. Tiedostamattomaan kollektiiviseen käyttäytymismalliin viittaa myös Savonlahden päähenkilö seuratessaan sometrendien yhteneväisyyksiä: "Instagramista ja Facebookista sain seurata, kuinka ihmiset ympäri Suomen olivat nauttineet aamiaiseksi smoothieita kulhoista. [--] 'Kulhoruuat' olivat muodissa." (ET, 127.) Teknologinen tiedostamaton saa myös konkreettisia piirteitä, kun älylaite toimii subjektin peilinä:

Avasin kännykkäkamerani nähdäkseni, miltä näytin. Ehkä tänään olin lumoava. Katsoin ruutua. Kasvoni punoittivat. Nenänpieleni kiilsivät. Hiukseni olivat rasvaiset [--]. Kameran perspektiivi teki kaksoisleuastani kolminkertaisen. Otsaani ja leukaani oli tullut finnejä. (ET, 127.)

Arkisen puuhastelun kuvaus tuottaa siis näkymän digitaaliseen aikalaiskulttuuriin. Teknologisen tiedostamattoman kutsu liittyy nimenomaan kaupallistuneeseen arkeen. Rita Felskin $(2000,78,90)$ mukaan subjekti ei pääse jokapäiväisen elämän kaupallista estetisointia pakoon - niin kokonaisvaltaisesti se on valloittanut kaikki elämän alueet, myös sisäisyyden - vaikuttaessaan täysin normaalilta kehitykseltä. Ilmiön juuret ovat moninaiset: yhtäältä vaikuttamassa ovat kapitalismin, teollistumisen ja kaupungistumisen, toisaalta mediaviestinnän ja erityisesti mainonnan hybridisoituminen.

Savonlahden ja Ekholmin teosten kaupallistuneen somearjen keskeisyys aikalaiskuvauksessa sekä teknologisen tiedostamattoman ongelmallisuus suhteessa inhimilliseen kanssakäymiseen ovat huomioita, joiden perusteella sosiaalista mediaa sivuavalla kirjallisuudella on paikkansa aikalaiskirjallisuudessa. Teoksen ilmaistessa tietyssä ajassa ja paikassa yleisesti vallitsevan konfliktin siitä tulee ideologiakritiikin kannalta kiinnostava.

\section{Teknologinen tiedostamaton}

Suomalaista romaania on perinteisesti pidetty yhteisöllisiä toimintatapoja tutkivana tilana, ja 2000-luvun kotimainen proosa on ollut kiinnostunut kommunikaatiota käsittelevistä kysymyksistä (Malmio 2019, 184, 203). Ekholmin ja Savonlahden romaanit jatkavat konventiota kuvaamalla teknologiavälitteistä kommunikaatiota ja osallistuvat samalla kansainväliseen dialogiin. Somearjen kuvaus liittää tarinan henkilöt osaksi omaa aikaamme, mutta digitaaliset laitteet eivät ole glorifioinnin kohde tai kasvun ja kehityksen motiiveja. Kyse on 
digitaalisten laitteiden ja digitaalisen kulttuurin nopean kotoutumisen ja sen seurausten tarkastelusta.

Rakkaus niinku -romaanissa teknologian representaatiot esiintyvät typografiassa, kielessä ja dialogissa. Intermediaalisen ja metafiktiivisen kerronnallisen rakenteen kautta ne ilmentävät valtaa, joka teknologialla ja digitaalisella kulttuurilla on yksilöön. Savonlahdella somerepresentaatiot rytmittävät päähenkilön elämää ja siten myös kerrontaa: "[K]irjoitan WhatsAppiin", "'[L]uin' kirjaa eli selasin Twitteriä, Instagramia, Jodelia ja Facebookia", "Avasin kännykkäkameran nähdäkseni, miltä näytin" ja "[P]äädyin lukemaan vauva.fi:n keskustelua" (ET, 13, 78, 128, 134).

Intermediaalisen esitystavan lomassa romaanien henkilöhahmot vertaavat itseään edelliseen sukupolveen ja havainnoivat status- ja positioeroja. Joonan ystävä kommentoi:

Tunteeks kukaan edes ketään kenel olis selvät sävelet, koulu, asuntolaina, lapset, koira, ura, harrastukset, isompi asunto, kesämökki, isompi auto, eläke, pienempi auto, hautajaisissa ramppaminen, arvokas poismeno..." Nyt on aika kantaa vastuu”... Ei kenelläkään mun tutulla oo tota. Kaikki on lost. (RN, 363.)

Savonlahden päähenkilö toteaa, kuinka hänen äidillään oli samanikäisenä jo puoliso ja kaksi lasta ja kuinka vanhempien ikäluokan mallin mukaan oikealle uralle ajaudutaan automaattisesti: "En koskaan ollut ajatellut, että makaisin 34-vuotiaana yksin parvekkeella Kalliossa ja katselisin ylös ja alas nousevaa vatsaani” (ET, 146). Lainaukset korostavat henkilöhahmojen riittämättömyyden tunnetta ja suhdetta sukupolvensa kipukohtiin.

Riittämättömyyden tunnetta voi lähestyä reaktiona "elämään, josta on tullut yksilöiden välistä kilpailua rajattomien mahdollisuuksien ympäristössä" (Purokuru \& Paakkari 2015, 163), jollaiseksi tilaksi myös sosiaalinen media teoksissa hahmottuu. Esimerkiksi Savonlahden romaanin päähenkilö kriisiytyy ihmissuhdetarjonnan äärellä: "Kauhukuvat vilistivät silmissäni. Ehkä poikaystäväni oli jatkanut tietämättäni Tinderin selailua ja löytänyt sieltä pitkähiuksisen naisen [--]. Heitä minä ajattelin, kun pyörin sängyssäni ja tunsin itseni surkimukseksi”. (ET, 57.) Syntyy kierre, jossa riittämättömyyden tunne saa subjektin toistamaan somekäyttäytymistään sovellusten kannustamana. Joona päättää tallentaa kaiken digitaaliseen muotoon, ja Savonlahden päähenkilö selaa eri sovelluksia päätyen lopulta Tinderiin. Hän päättää toimia deittipalvelussa harkiten, mutta lopputulos on päinvastainen. Tinder-tapaamisen jälkeen hän on "henkisessä vuoristoradassa" (ET, 231).

Arvonmuodostuksen logiikka ei tue ajatusta, jossa subjekti voisi olla käyttämättä somea ja tuottamatta dataa. Savonlahden päähenkilön tapa mennä parvekkeelle makaamaan on heikkoa vastarintaa ympäristön vaateita vastaan. Toisaalta se on myös epäonnistumisen symboli: mahdollisuus joutilaana makailemiseen ei ole oma valinta. Työttömyys, joutilaisuus, rakkaudettomuus 
ja masennus tiivistyvät parvekkeella makaamiseen: "Elämä valui ohitseni, enkä minä tiennyt, mitä halusin ja vaikka olisin tiennyt, ei tämä ollut vain minun käsissäni. Jonkun pitäisi rakastaa minua”. (ET, 146-147.) Maatessaan parvekkeella päähenkilö ei liity datavirtaan eikä siten tuota julkaisusisältöä ja arvoa.

Teknologista tiedostamatonta korostaa myös jatkuva puhe someilmiöistä. Savonlahden henkilöhahmojen puheenaiheet valikoituvat sen mukaan, mitä ajankohtaista milläkin somealustalla on meneillään. Ekholmilla myös chatdialogin tuominen typografisesti osaksi kerrontaa on osa teoksen intermediaalista luonnetta ja toistaa pikaviestimistä tuttuja näkymiä kaunokirjallisin keinoin. Syntyy intermediaalista ja dataistista nykymaailmaa kommentoivaa poetiikkaa, joka on herkistynyt tutkimaan subjektin suhdetta someen, teknologiavälitteiseen kommunikaatioon ja esitykselliseen julkaisemiseen. Toistuvat sosiaalisen median representaatiot viittaavat siihen, että some vuotaa sekä muotopiirteisiin että teemaan. Digitaalisen huomiotalouden kritiikkiä esiintyy siis sekä kuvauksen että rakenteen tasolla.

Ekholmin romaanin muoto korostaa sitä, millaisessa itsensä näyttelijän roolissa julkaisija on. Joonan tapa lähestyä tapaamiaan ihmisiä tallenteeseen vangittavana ja hänen taloudellisia näkymiään palvelevana materiaalina ja hyödykkeenä johtaa huomioon, että teknologiavälitteisessä kommunikaatiossa muilla subjekteilla on statistin ja hyödykkeen rooli: "[R]iistät niiltä katseen kohteilta niiden toimijuuden [--] ja mut lukijana pakotetaan näkemään se tilanne sun näkökulmasta" (RN, 221). Se, mikä henkilöhahmoille on teknologista tiedostamatonta, on kirjailijalle tietoinen valinta pohtia teemaa.

Juuri romaanin laji sallii kaunokirjallisuuden päälajien ja eri mediumien yhdistelyn ja mahdollistaa somen valumajäljen esittämisen luontevasti. Dialogiset elementit romaanissa syventävät näkemystä siitä, että inhimillisen elämän tapahtumia ei voida kelata, keskeyttää tai tallentaa - toisin kuin somealustoilla - ja ihmiset kohtaavat toisensa samassa ajassa ja paikassa, offline. Vaikka Ekholmin romaania voi pitää osin kokeilevana, se muistuttaa pohjimmiltaan tuntemaamme elämismaailmaa. Toisaalta kun kuvataan nykyihmisen toiminnan saamia järjettömiä sävyjä, alkaa omaksuttu tapa hahmottaa todellisuutta sosiaalisen median avulla näyttäytyä korostetun prosteettisena - ja prosteettinen elementti teknologisena tiedostamattomana:

miks ihmiset kuvaa itteään? ehkä se siin hetkessä jotenki tuntuu palkitsevalta se tieto siitä et joku muisto jää, että asiat ei vaan tapahdu ja katoo. muistiproteesi! (RN, 171. Kursiivi lisätty.)

Savonlahden romaanin tapa raportoida sometottumuksia kertookin näiden rutiinien vaikutuksista. Eron hetkellä poikaystävä kysyy, mitä nainen aikoo tehdä välittömästi eron jälkeen. Nainen antaa käytännöllisen vastauksen: "Luultavasti istun tähän sängyn laidalle ja poistan sinut Facebook-kavereistani[.] Sitten lopetan seuraamisesi Instagramissa ja Twitterissä ja käyn nukkumaan". 
(ET, 77.) Poikaystävä syyllistää naista virtuaalierosta: "Ai sinä olet [--] deletoija" (mt.). Välirikko sosiaalisessa mediassa saa painokkaamman arvon kuin ero lähisuhteessa. Savonlahden romaani ei yllä Ekholmiin verrattuna samalle aikalaisdiagnoosin tasolle, mutta oireinen se kiistämättä on.

Teknologinen tiedostamaton kiteytyy Ekholmin romaanissa repliikissä, joka eksplikoi, että aikalaisia yhdistävät olosuhteet ovat "täysin tarkoituksellisesti tuotettu valvonnan ja hallinnan muoto. Joka on ominainen tälle nimenomaiselle historialliselle tilanteelle". (RN, 249.) Sitaatti korostaa digitalisaatiokehitykseen sisältyvää valvonnan ja hallinnan elementtiä, joka koskettaa jokaista digitalisoituneessa yhteiskunnassa elävää kansalaista. Joona päättelee, että pitää keksiä "uudet tavat tehdä vastarintaa", mutta jos tosielämää tallentava ja toistava teos on Joonan yritys, se ei ehkä vastarintaa olekaan.

Myös eräs romaanin sivuhenkilö viittaa foucault'laisittain alistuvaan subjektipositioon: "Tuo on just tuota 'biopoliittista taloutta'. Että elämän intiimeimmät puolet on niinku kääntyneet nurin, sisäisyyvestä on tullut ulkopuolta, elämän prosessista on tullut tuote biopoliittisen talouven markkinoilla." (RN, 380.) Näin henkilöasetelma avaa lukijalle sitäkin, mitä Joona ei huomaa: "Se just liittyy sisäistettyyn hallintaan. [--]. Koskaan ei pääse pomon käskyjä pakoon." (RN, 380.) Teknologinen tiedostamaton on "pomo [--] siun pään sisällä" (RN, 380). Tosin ajoittain, varsinkin teoksen loppua kohden, Joona havahtuu hahmottamaan tiedostamattomia alistussuhteita: "Jotenki [puhun] siitä miten me vapaaehtosesti suostutaan alistamaan itseämme" (RN, 413). Teoksen diagnosoiva elementti ei siis henkilöidy Joonaan vaan on kokonaisteoksen ominaisuus.

Romaaneissa somejulkaisija on tilanteessa, jossa jokainen hereillä olon hetki on ansaitsemisen aikaa: subjekti alistaa somerepresentaationsa virtuaalisen suosion reaaliaikaiselle arvioinnille mitatakseen, miten hänen persoonallinen brändinsä kehittyy. Ajasta tulee ekonominen resurssi eikä sitä voi enää käyttää siihen, ettei tee mitään. Tämä on ajan, tilan ja teknologisen tiedostamattoman kylmä leikkauspiste: ei-kaupallinen tila menetetään ja kaikki teot nähdään kaupallisen potentiaalin näkökulmasta. Savonlahden romaanin päähenkilö vastustaa kehityskulkua menemällä parvekkeelle makaamaan. Ekholmin romaanin vastarinta on monitahoisempaa: viesti on, ettei päähenkilö pysty ratkaisemaan vallitsevaa olotilaa yksin.

\section{Lopuksi}

Huomiotalous, teknologiavälitteinen kommunikaatio ja sosiaalisen median käytön vaikutukset ja seuraukset tematisoituvat tarkastelemieni romaanien rakenteessa, sisällössä ja kielessä. Sosiaalinen media on läsnä teosten eri tasoilla ja ohjelmistojen logiikka ohjaa päähenkilöiden arkea. Huomiotaloustutkimuksen valossa kaunokirjallisten somejulkaisijoiden käytös hahmottuu nar- 
sistiseksi ja banaaliksi mutta myös toisohjautuneeksi: Sosiaalisessa mediassa vallitsee huomiotalouden tarpeita palveleva normi, ja suosion tavoittelu näillä keinoin tuottaa monesti itseinhoa. Vaikka somen kutsuun vastaamisessa on etuja muun muassa verkostoitumisessa, tuottaa se romaanien mukaan myös erillisyyttä ja yksinäisyyttä.

Analyysin käsitteellisenä lähtökohtana teknologinen tiedostamaton osoittautuu käsitellyissä romaaneissa sikäli rajoittuneeksi, ettei se selitä, mistä henkilöhahmojen hetkittäinen itsereflektiivinen somepuhe juontuu. Siitä huolimatta sosiaalista mediaa kohosteisen usein käyttävien henkilöhahmojen teknologiavälitteinen toiminta näyttäytyy obsessiivisena tilana, jossa kerrottu elämä rytmittyy digitaalisen banaalin ehdoilla.

Sisäistetyn teknologisen tiedostamattoman representaatio uudessa kotimaisessa fiktiossa ilmentää nähdäkseni valtaa, joka teknologialla ja ohjelmistoyrityksillä on yksilöön. Kyse on digitaalisen kulttuurin nopeasta kotoutumisesta ja sen seurausten tarkastelusta. Tulevassa tutkimuksessa olisikin syytä eritellä esimerkiksi digitaalisen kommunikaation moninaisuuden kuvauksia fiktiossa. Representaatioilla lienee erityyppiset funktiot tapauksissa, joissa käsitellään kahdenvälistä pikaviestittelyä tai sosiaalisessa mediassa jaettuja esityksellisiä julkaisuja. Erityisesti nuortenkirjallisuuden sosiaalisen median esityksiä olisi kiintoisaa tarkastella olettaen, että ne tuovat yhteiskunnallis-institutionaaliseen diskurssiin toisentyyppisiä näkökulmia kuin (koulutus)poliittinen tai taloudellinen puhetapa. ${ }^{6}$

\section{Viitteet}

I Teknologisen tiedostamattoman käsite juontuu Patricia Clough'n Auto Affection: Unconscious Thought in the Age of Tele-Technology -teoksen (2000) sisältämistä teknologianäkemyksistä. Thrift (2005) viittaa käsitteen kohdalla ko. teokseen, vaikkei Clough käytä termiä.

2 Ohjelmistoituminen kuvaa, kuinka ohjelmistot ja algoritmit jäsentävät ja rytmittävät digitalisoituvia yhteiskuntia (Manovich 2013).

3 Termi huomiotalous (attention economy) kuvaa vuosituhannen vaihteen taloudellista muutosta, jossa kaupallista toimintaa ohjaa tarve kiinnittää yleisön huomio. Yksilölliset huomion kohdentamisen valinnat ovat ratkaiseva arvonmuodostuksen tekijä.
Koska yksilön huomiokyky on rajallinen, resurssista kilpaillaan, mikä tapahtuu pitkälti digitaalisissa ympäristöissä. (Tanner 2020, 60-66.) Talouden nykyvaihetta voisi luonnehtia huomiotalouden piirteitä korostettaessa myös esimerkiksi immateriaalitaloudeksi tai kognitiiviseksi kapitalismiksi (Sevänen 2018, 79-80).

4 Käsitän dataismin tässä Yuval Noah Hararin $(2017,394)$ tapaan ideologiana, jonka korkein arvo on informaation vapaa liike tietoverkoissa.

5 Ekholmin romaanin metafiktio muuttuu humoristiseksi esimerkiksi kohdassa, jossa keskustelukumppani tajuaa, että Joona tallentaa parhaillaan heidän keskusteluaan (RN, 85). Mainittakoon myös 
romaanin loppupuolelle sijoittuva kohtaus, jossa lintujen laulu tuo mieleen lähinnä Twitterin eikä niinkään luontoelämystä: "Twittering Machine" (RN, 395). Richard Seymourilta on 2019 ilmestynyt samanniminen somekriittinen manifesti, mutta vuoden 2016 kontekstissa sitaatti viitannee samannimiseen kuvataideteokseen.

6 Artikkelin kirjoittamiseen on saatu
Suomen Kulttuurirahaston tukea. Artikkeli on osa väitöskirjatutkimusta ("Subjektiasemia ja sosiaalista mediaa suomalaisessa proosassa 2000-2022"), jonka tavoitteena on tehdä kotimainen sosiaalista mediaa sivuava teosjoukko tunnetuksi ja raportoida analyyttisesti siinä esiintyvien sosiaalisen median representaatioiden luonnetta.

\section{Aineisto}

Ekholm, Johannes 2016. Rakkaus niinku [= RN]. Helsinki: Otava.

Savonlahti, Sisko 2018. Ehkä tänä kesänä kaikki muuttuu [= ET]. Helsinki: Gummerus.

\section{Kirjallisuus}

Bauman, Zygmunt 2002. Notkea moderni. (Liquid Modernity, 1999.) Suom. Jyrki Vainonen. Tampere: Vastapaino.

Clough, Patricia 2000. Auto Affection: Unconscious Thought in the Age of Tele-Technology. Minneapolis: University of Minnesota Press.

Dinnen, Zara 2018. The Digital Banal: New Media and American Literature and Culture. New York: Columbia University Press. DOI: 10.7312/dinn18428.

Felski, Rita 2000. Doing Time: Feminist Theory and Postmodern Culture. New York: NYU Press.

Glazer, Jeremy, Robyn Seglem \& Antero Garcia 2021. Continuity and Change? Reading Young Adult Literature through a Technology-Focused Critical Lens. Journal of Adolescent \& Adult Literacy 64(6), 675-682. DOI: 10.1002/jaal.1151.

Fludernik, Monika 2003. Chronology, time, tense and experientiality in narrative. Language and Literature 12(2), 117-134. DOI: 10.1177/0963947003012002295.

Harari, Yuval Noah 2017. Homo Deus-huomisen lyhyt historia. (Homo Deus-A Brief History of Tomorrow, 2015). Suom. Jaana Iso-Markku. Helsinki: Bazar.

Hietasaari, Marita 2011. Totta, tarua vai narrinpeliä? Lars Sundin Siklax-trilogian (meta)fiktiivinen historiankirjoitus. Oulu: Oulun yliopisto.

Hsu, Stephanie 2016. Tao Lin's Taipei as an Aesthetic Experiment in Autistic Jouissance. Literature interpretation theory 27(3), 191-212. DOI: 10.1080/10436928.2016.1207277.

Kelosaari, Artemis 2020. Äijäkirjailijoita tarvitaan enemmän kuin koskaan. Parnasso 2020(3), 8-9.

Kitchin, Rob \& Martin Dodge 2011. Code/Space: Software and Everyday Life. Cambridge, MA: The MIT Press. DOI: 10.7551/mitpress/9780262042482.001.0001.

Licoppe, Christian 2004. "Connected Presence": The Emergence of a New Repertoire for Managing Social Relationships in a Changing Communication Technoscape. Environment and Planning D: Society and Space 22(1), 135-156. DOI: 10.1068/d323t.

Logrén, Anna 2020. Vartijoita ja vuoron vaihdoksia: Keskustelua hyvästä kirjallisuudesta kirjallisuuskritiikin muuttuvalla kentällä. Teoksessa Kirjallinen elämä markkinaperustaisessa mediayhteiskunnassa. Toim. Elina Arminen, Anna Logrén \& Erkki Sevänen. Tampere: Vastapaino, 115-142.

Luettua ja maistettua -blogi. § Ehkä tänä kesänä kaikki muuttuu (kirjoittanut Sisko Savonlahti). 19.9.2018. https://luettua-ja-maistettua.blogspot.com/search/label/Savonlahti\%20Sisko.

(11.4.2021). 
Lummaa, Karoliina \& Lea Rojola 2014. Johdanto: Mitä posthumanismi on? Teoksessa Posthumanismi. Toim. Karoliina Lummaa \& Lea Rojola. Turku: Eetos, 13-32.

Malmio, Kristina 2019. Vanhat ja uudet leikit. Postmodernismi ja sen "yli" kirjoittaminen 2000luvun suomenruotsalaisissa romaaneissa. Teoksessa Muistikirja ja matkalaukku: Muotoja ja merkityksiä 2000-luvun suomalaisessa romaanissa. Toim. Elina Arminen \& Markku Lehtimäki. Helsinki: SKS, 177-210.

Manovich, Lev 2013. Software Takes Command: Extending the Language of New Media. London: Bloomsbury Academic. DOI: 10.5040/9781472544988.

Mäkelä, Maria 2019. Literary Facebook Narratology: Experiantiality, Simultaneity, Tellability. Partial Answers 17(1), 159-182. DOI: 10.1353/pan.2019.0009.

Noppari, Elina \& Mikko Hautakangas 2012. Kovaa työtä olla minä: Muotibloggaajat mediamarkkinoilla. Tampere: Tampere University Press.

Ojajärvi, Jussi, Erkki Sevänen \& Liisa Steinby 2018. Kapitalismi ja sen tutkiminen suomalaisen kirjallisuuden näkökulmasta. Teoksessa Kirjallisuus nykykapitalismissa. Suomalaisen kirjallisuuden ja kulttuurin näkökulma. Toim. Jussi Ojajärvi, Erkki Sevänen \& Liisa Steinby. Helsinki: SKS, 7-52.

Pietilä, Antti-Pekka 2018. Uutisissa valheita, valheista uutisia. Helsinki: Art House.

Piippo, Laura 2019. Ylenpalttisuutta ja äärimmäisyyskokemuksia. Jaakko Yli-Juonikkaan Neuromaani 2000-luvun eksessiromaanina. Teoksessa Muistikirja ja matkalaukku: Muotoja ja merkityksiä 2000-luvun suomalaisessa romaanissa. Toim. Elina Arminen \& Markku Lehtimäki. Helsinki: SKS, 211-240.

Purokuru, Pontus \& Antti Paakkari 2015. Riittämättömyys. Teoksessa Prekarisaatio ja affekti. Toim. Eeva Jokinen \& Juhana Venäläinen. Jyväskylä: Nykykulttuuri, 153-170.

Ridell, Seija 2011. Elämää Facebookin ihmemaassa. Sosiaalinen verkkosivusto käyttäjiensä kokemana. Tampere: Tampereen yliopisto.

Rippl, Gabriele 2015. Introduction. Teoksessa Handbook of Intermediality: Literature - Image - Sound -Music. Ed. Gabriele Rippl. Berlin, München, Boston: De Gruyter, 1-32. DOI: 10.1515/9783110311075-002.

Saariketo, Minna 2018. Koodin rytmittämät kokemusmaisemat. Kulttuurintutkimus 35(1-2), 37-49.

-2020. Kuvitelmia toimijuudesta koodin maisemissa. Tampere: Tampereen yliopisto.

Sarja, Tiina 2016. Kuka oikein tietää: Kun mielipide haastoi tieteen. Jyväskylä: Docendo.

Seppänen, Jaana 2016. Chat ja tsirp tsirp. Parnasso 2016(6-7), 40-43.

Sevänen, Erkki 2018. Talous ja yhteiskunta nykykapitalismissa ja sitä edeltävissä kapitalismin vaiheissa. Teoksessa Kirjallisuus nykykapitalismissa. Suomalaisen kirjallisuuden ja kulttuurin näkökulma. Toim. Jussi Ojajärvi, Erkki Sevänen \& Liisa Steinby. Helsinki: SKS, 55-98.

Seymour, Richard 2019. Twittering Machine. London: The Indigo Press.

Sihvonen, Jukka 2014. Ihmiskuvia, eläimiä ja antropologisia koneita. Teoksessa Posthumanismi. Toim. Karoliina Lummaa \& Lea Rojola. Turku: Eetos, 81-108.

Suominen, Jaakko, Sari Östman, Petri Saarikoski \& Riikka Turtiainen 2013. Sosiaalisen median lyhyt historia. Helsinki: Gaudeamus.

Tanner, Simon 2020. Delivering Impact with Digital Resources: Planning Strategy in the Attention Economy. London: Facet Publishing. DOI: 10.29085/9781783302529.

Thrift, Nigel 2005. Knowing capitalism. London: SACE Publications.

Thrift, Nigel \& Shaun French 2002. The automatic production of space. Transactions of the Institute of British Ceographers 27(3), 309-335. DOI: 10.1111/1475-5661.00057.

Weigel, Anna Lena 2018. "Fictions of the Internet": From Intermediality to Transmedia Storytelling in 21st-Century Novels. Väitöskirja. Helsingin yliopisto \& Justus Liebig University Giessen.

Östman, Sari 2015. Millaisen päivityksen tästä sais? Nykykulttuurin tutkimuskeskuksen julkaisuja 119. Jyväskylä: Nykykulttuuri. 